\title{
UM HERÓI DE DUAS FACES - SOBRE AS AMBIGUIDADES DO IMPOSTOR FELIX KRULL
}

http://dx.doi.org/10.11606/issn.2237-1184.v0i27pl14-130

Mário Luiz Frungillo

Universidade Estadual de Campinas (UNICAMP)

\section{RESUM0}

O romance Confissões do Impostor Felix Krull (Bekenntnisse des Hochstaplers Felix Krull), de Thomas Mann, combina elementos do romance de formação e da novela picaresca. Essa mescla confere uma forte ambiguidade ao caráter do protagonista, que justifica suas imposturas elaborando o que poderíamos chamar de uma "teoria da permutabilidade": numa sociedade em que os papéis sociais poderiam ser trocados sem que ninguém percebesse, a impostura deixa de ser uma transgressão para se tornar a própria regra.

\section{ABSTRACT}

Thomas Mann's novel Confessions of Felix Krull, Confidence Man (Bekenntnisse des Hochstaplers Felix Krull) combines elements of the Bildungsroman and the picaresque novel. This mixture confers a strong ambiguity to the character of the protagonist, who justifies his impostures by elaborating what we might call a "theory of interchangeability": in a society in which social roles could be exchanged without anyone noticing, imposture ceases to be a transgression to become the rule itself.

\section{PALAVRAS-CHAVE:}

Romance de formação; Novela picaresca; Thomas Mann; Felix Krull.

KEYWORDS:

Bildungsroman;

Picaresque novel;

Thomas Mann;

Felix Krull. 
1 o abrir o romance Confissões do Impostor Felix Krull (Bekenntnisse des Hochstaplers Felix Krull), de Thomas Mann, o leitor se depara, logo de início, com uma série de afirmações desconcertantes por parte do narrador. Ao mesmo tempo que se preocupa em afirmar seu pertencimento a uma classe social respeitável, ele acrescenta aos elementos que dão apoio a esta afirmação uma série de outros que a põem em dúvida: descende de uma família burguesa distinta, porém licenciosa. Esteve, juntamente com sua irmã, aos cuidados de uma preceptora suíça, mas esta teve de deixar a casa quando veio à tona seu relacionamento com o pai de ambos. Este, por sua vez, era produtor de um vinho espumante de apresentação pomposa, porém de qualidade suspeita. Se demonstra aspirações de gosto requintado, ficamos também sabendo que se evadiu da escola, viveu uma vida de fraudes e passou uma temporada na prisão ${ }^{1}$.

Essa série inusitada de afirmações conflitantes nos prepara não tanto para a descrição de uma vida singular (pois a biografia de um impostor não seria propriamente uma raridade), mas para o modo peculiar que o protagonista escolhe para nos dar a conhecer sua biografia. Ele se apresenta como alguém que desde cedo aspira a fugir de seu ambiente estreito e opressivo, da cidadezinha mesquinha em que nasceu e da escola que frequenta, com seus professores autoritários e seus alunos medíocres. Ficamos desde logo conhecendo suas aspirações à nobreza, ditadas pela certeza de ter sido "talhado em madeira mais fina" e destinado a um futuro mais promissor do que aquele ambiente lhe pode proporcionar. Em suma: ao iniciar sua autobiografia, Felix Krull faz o possível para nos convencer de que a história de sua vida, contada por escrito, daria um belo romance, mas não um folhetim qualquer, e sim um exemplar da prestigiosa vertente do romance de formação, colocando-o na ilustre linhagem que tem como protótipo Os anos de aprendizado de Wilhelm Meister (1795-6), de Goethe. Essa intenção fica visível logo no subtítulo do romance, "Der Memoiren erster Teil" (Primeira parte das memórias), vazado numa sintaxe meio antiquada, que evoca imediatamente a de Goethe no Fausto: “Der Tragödie erster / zweiter Teil" (Primeira / segunda parte da tragédia). Assim também as circunstâncias de seu nascimento, parto difícil num dia favorável - a posição das estrelas no caso de Goethe, um domingo de maio no caso de

\footnotetext{
${ }^{1}$ MANN, Thomas. Confissões do impostor Felix Krull. Tradução e posfácio de Mário Luiz Frungillo. São Paulo: Companhia das Letras, 2018, pp. 1 ss.
}

115 | D O S S I Ê : ROMANCE DE FORMAÇ̃̃O - CAMINHOS E DESCAMINHOS DO HERÓI 
Felix - evoca o início da autobiografia do maior poeta alemão, De minha vida: poesia e verdade. Não contente com isso, Felix como que se apropria, sem mencioná-la textualmente, de uma expressão paradoxal de Goethe para justificar suas pretensões de nobreza: a do mérito inato. De fato, assim como Goethe afirmava que, ao receber seu diploma de nobreza seu sentimento foi o de que apenas estavam the dando aquilo que lhe cabia desde sempre ${ }^{2}$, Felix chega a especular com uma possível irregularidade em sua linhagem que o colocasse na descendência em linha direta de algum nobre, pois ao examinar a galeria dos retratos de seus antepassados pendurados nas paredes da casa, não encontra entre eles nenhum que pudesse ser responsável por um rebento daquela qualidade.

Ocorre que, no desenrolar de sua narrativa, ele sai da cidadezinha renana onde nasceu para uma temporada de vagabundagem em Frankfurt, dali para Paris, onde se exercita numa vida dupla de empregado de hotel e bon-vivant, mantida à custa de fraudes e furtos e, por fim, trocando de identidade com um marquês frequentador do hotel, a Portugal, onde se faz passar por um jovem aristocrata no início de uma viagem de formação ao redor do mundo. Assim, o protagonista desse suposto romance de formação poderia também ser comparado a um pícaro, o que aparentemente nos colocaria diante de um novo paradoxo pois, se é inegável que há algo em comum entre o romance de formação e o romance picaresco, uma vez que ambos, em linhas gerais, descrevem, o percurso rico em vicissitudes, experiências e aprendizado de uma personagem até o ponto em que ela encontra seu lugar no mundo, também se deve levar em conta que cada um deles tem características que os tornariam, em sua forma tradicional, inconciliáveis.

Tendo isso em vista, não se pode afirmar que as Confissões do impostor Felix Krull são uma espécie de híbrido na qual se combinam tanto elementos do romance de formação quanto da novela picaresca sem antes resolver as dificuldades teóricas implicadas em tal afirmação. Ao empreender sua análise do romance, Helmut Koopmann chega mesmo a afirmar taxativamente que a ideia de formação e a prática da impostura se excluem mutuamente, e apresenta um sumário das dificuldades da crítica para classificar o romance. Quanto a ser um romance de formação temos que, de um lado o próprio protagonista acrescenta um caráter formador à suas experiências, e indica a necessidade de uma socialização crescente (o que, no entanto, deveria ficar para o segundo volume, jamais publicado, do romance, quando o protagonista se casaria e se tornaria pai). Além disso, diálogos e aventuras teriam, no romance, as mesmas funções estruturais que têm num romance de formação tradicional. Por outro lado,

\footnotetext{
2 ECKERMANN, Johann Peter. Conversações com Goethe nos últimos anos de sua vida: 1823-1832. Tradução de Mário Luiz Frungillo. São Paulo: Editora Unesp, 2016, pp. 608-9.
}

116 | D O S S I E : ROMANCE DE FORMAÇÃO - CAMINHOS E DESCAMINHOS DO HERÓI 
a ideia da formação de um caráter individual estaria ausente das Confissões, e faltaria ao mundo e à sociedade descritas nelas a qualidade de pontos de orientação para a formação de um indivíduo excepcional. Também o acúmulo de cenas teatrais, nas quais Felix está continuamente desempenhando um papel, daria a suas aventuras apenas o caráter de mutações de seu próprio ser, pois apesar de todas as transformações ele permaneceria sempre o mesmo.

Como elementos da picaresca, a crítica apontou a busca de ascensão social a partir de uma posição inferior. Além disso, as viagens do protagonista, descritas de um modo um tanto exibicionista, teriam de fato algo da peregrinação de um pícaro. A isso viria se acrescentar o caráter episódico da narrativa, que apresenta uma série contínua de aventuras das quais o herói em geral se sai bem, aí incluídas suas experiências eróticas. Como argumentos contrários, as condições sociais de que Felix parte não correspondem às de um pícaro como o Lazarillo de Tormes, são de fato muito superiores a elas, e as dificuldades com que este tem de lutar são também muito maiores. Faltaria ainda a Felix uma atitude de oposição, pois ele reafirma o tempo sua perfeita concordância com os padrões sociais vigentes. Por isso, Koopmann considera que categorias como romance de formação, ou paródia deste, e novela picaresca são insuficientes para caracterizar a obra. Poderíamos encontrar nela traços isolados de tudo isso, sem que por isso ela pudesse constituir um exemplar de qualquer um desses gêneros ${ }^{3}$.

O primeiro problema de considerações como essas é ignorar que a obra não pretende mesmo ser um representante tradicional nem de um nem de outro desses gêneros. Trata-se de um experimento com ambos, e é só o seu caráter experimental que permite ao autor realizar a síntese entre características tão díspares.

A abordagem de Koopmann também parece partir do princípio de que é possível estabelecer uma tipologia mais ou menos firme dessas duas vertentes do romance (ou de quaisquer outras). A primeira dificuldade surge quando tomamos cada caso em particular e tentamos enquadrá-lo nessa tipologia. O conceito de romance de formação tem uma história acidentada. Inicialmente foi tido como uma espécie exclusivamente alemã, mas com o correr do tempo foi atribuído a uma profusão tão grande de romances que por fim sua pertinência não podia deixar de ser questionada, a não ser que se admitisse uma abertura maior para o conceito a fim de poder situar nele a diversidade de exemplos que em maior ou menor grau se aproximam de seu protótipo e reivindicam seu parentesco com ele 4 .

\footnotetext{
${ }^{3}$ KOOPMANN, Helmut. "Bekenntnisse des Hochstaplers Felix Krull". In: Helmut Koopmann (Org.) Thomas Mann Handbuch. Frankfurt: Fischer, pp. 529-30.

${ }^{4}$ Para uma abordagem abrangente desse problema, ver: MAAS, Wilma Patrícia. O cânone mínimo. O Bildungsroman na história da literatura. São Paulo: Editora Unesp, 2000, pp. 9-81.
}

117 | D O S S I Ê : ROMANCE DE FORMAČ̃a-CAMINHOS E DESCAMINHOS DO HERÓI 
Do mesmo modo, o conceito de romance picaresco, que de início foi considerado uma espécie exclusivamente espanhola, surgiu das interpretações de duas obras que se situam em sua origem, o Lazarillo de Tormes (1554), de autor anônimo, e o Guzmán de Alfarache (1599-1604), de Mateo Alemán, e também foi utilizado para designar uma longa série de romances que em maior ou menor grau se aparentavam a elas. E uma tentativa de se estabelecer, a posteriori de seu largo emprego ao longo do tempo, uma caracterização muito rígida dessa vertente, pode chegar a um resultado tão desconcertante quanto o de um especialista como Francisco Rico, para quem só há dois romances picarescos que mereçam de fato esse nome, justamente aqueles que estão no início de sua linhagem. Parece muito pouco para consolidar uma vertente dentro do gênero, além de ser uma resposta insatisfatória para o largo uso que se fez do conceito ao longo do tempo 5 .

Além do mais, é preciso considerar que, na passagem da literatura espanhola para a alemã, quando, tomando por modelo o romance picaresco, se originou o que viria a ser chamado de Schelmenroman, algumas coisas se perderam, e outras se ganharam. Para citar um exemplo: ninguém poderá negar ao Schelmuffsky (1696-7) de Christian Reuter a reivindicação de ser um Schelmenroman, pois esta vem expressa não apenas no título do livro, como também no local de publicação informado no frontispício da primeira edição, a cidade fictícia de Schelmerode. No entanto, Reuter parece ter compreendido a picaresca como uma série de aventuras e burlas, não necessariamente no mesmo sentido que ocorrem numa obra como o Lazarillo de Tormes. Ao seu Schelmuffsky faltam a origem irregular e suas aventuras, embora às vezes o levem a situações difíceis, não são determinadas pela pobreza extrema, devem-se antes ao seu desejo de viajar, de escapar à perspectiva de uma existência rotineira mergulhada no tédio de uma profissão convencional. Em lugar de servir a um amo por quem será explorado e maltratado, ele se associa a um duque, que o acompanha durante boa parte da narrativa, até morrer num naufrágio.

Claro que se poderia argumentar que Reuter não compreendeu de fato o que vem a ser um romance picaresco, mas não se pode deixar de reconhecer que frequentemente, passando ao largo do anseio sistematizador da crítica, a história de como um gênero novo é assimilado, imitado e distorcido por outros autores em outros contextos dilui fronteiras e delimitações estreitas, criando dificuldades teóricas por vezes intransponíveis.

\footnotetext{
${ }^{5}$ Uma apresentação exaustiva do problema pode ser encontrada em: GONZÁLEZ, Mario M. A saga do anti-herói. Estudo sobre o romance picaresco espanhol e algumas de suas correspondências na literatura brasileira. São Paulo: Nova Alexandria, 1994, pp. 204-277.
}

118 | D O S S I Ê : ROMANCE DE FORMAÇ̃̃O - CAMINHOS E DESCAMINHOS DO HERÓI 
Quanto à filiação do Felix Krull a essas duas vertentes do romance, ela foi feita pelo próprio autor, mas em momentos diferentes e ao longo de um processo de composição dos mais acidentados 6 . Certamente a solução mais fácil para resolver a dificuldade de conciliar os dois seria tratar o caso como uma paródia do romance de formação. O próprio Thomas Mann o apresentou assim em texto escrito como introdução à leitura pública de um de seus capítulos. O Felix Krull seria, segundo o autor, produto de um processo que ele define como "da politização, da literarização, da intelectualização, da radicalização da Alemanha", o que significaria "sua 'humanização' no sentido ocidental político e sua desumanização no sentido alemão". Esse processo, visto de forma muito negativa, só seria representável por meio da paródia7. Mas, para além do fato de esta afirmação estar contaminada por seu trabalho, naquele mesmo período, nas Considerações de um apolítico, visível no tom nacionalista e na desconfiança em relação à democracia que perpassam o texto, ele também se refere a um estágio da composição da obra em que esta avançara apenas até o Sexto Capítulo do Livro Segundo. Devemos levar em conta que o Felix Krull, é obra de longuíssima gestação, iniciada por volta de 1905, ainda antes de A morte em Veneza (1912), mas que estava destinada a ser a última publicada por Thomas Mann, em 1954. Planejada inicialmente como uma novela, foi crescendo ao longo da escrita, até se tornar um romance que teria possivelmente pelo menos o dobro da extensão atual, caso sua composição não fosse interrompida pela morte do autor.

Ao retomar o trabalho com vistas à sua conclusão, Mann menciona também seu débito para com o Schelmenroman, mas ao fazê-lo se refere expressamente ao romance $O$ aventuroso Simplicissimus (1668-9), de Grimmelshausen. Contudo, embora seja comum considerá-lo como um Schelmenroman, o Simplicissimus é obra que encontramos citada como parte da genealogia do romance de formação com a mesma frequência que a vemos filiada à picaresca. Pois seu herói Simplicius parte de uma situação de pobreza e ignorância para, através das tribulações da Guerra dos Trinta Anos, atingir de fato um grande conhecimento do mundo. Mas sua conclusão é um desengaño, abandonando o mundo para ir viver numa ilha deserta. Assim, o protagonista do romance também tem e não tem relações com o pícaro. É de origem pobre, porém não irregular: seus pais são camponeses de vida honrada. Mais que isso, como, saberemos depois, ele é filho adotivo; seus verdadeiros pais pertenciam a nobreza e foram

\footnotetext{
${ }^{6}$ Uma detalhada história da composição do romance se encontra nos comentários elaborados por Thomas Sprecher e Monica Bussmann em colaboração com Eckhard Heftrich para a Große kommentierte Frankfurter Ausgabe, publicada pela S. Fischer em 2012.

7 MANN, Thomas. "O romance de formação". In: Travessia marítima com Dom Quixote: Ensaios sobre homens e artistas. Tradução de Kristina Michahelles e Samuel Titan Jr. Rio de Janeiro: Zahar, 2014, pp. 54-5.
}

119 | D O S S I Ê : ROMANCE DE FORMAÇ̃̃O-CAMINHOS E DESCAMINHOS DO HERÓI 
separados dele pelas vicissitudes da guerra. E será também à guerra que se deverão suas sucessivas ascensões e quedas, das quais não lhe virá, contudo, um entendimento com o mundo, e sim uma oposição a ele, muito diferente, porém, da de um pícaro em sentido estrito. Poderíamos chamar de formação a esse processo, embora não num sentido de estabelecer um equilíbrio entre eu e mundo, como seria de esperar num romance de formação em sentido estrito, e sim um afastamento intransponível entre eles.

Podemos, então, dizer que a filiação do Felix Krull à vertente da picaresca se dá tomando por referência um romance que transcende os limites daquela vertente, inclusive por uma ambientação social bem mais ampla e matizada do que a de seus modelos tradicionais. Tendo isso em vista, seria possível concluir que o Felix Krull não é mera paródia do romance de formação, seu herói não é meramente um pícaro travestido de burguês. A dimensão paródica desse romance atinge um grau de sofisticação e sutileza muito mais profundo. Não podemos afirmar que no seu protagonista o burguês seja mais ou menos falso do que o pícaro. Felix é as duas coisas ao mesmo tempo e na mesma medida.

Para compreender como o autor pôde operar essa fusão, é preciso primeiro considerar que, apesar de tudo, é possível apontar algumas semelhanças entre o romance de formação e a novela picaresca.

Como pontos em comum, podemos mencionar o início da narrativa na infância ou, pelo menos, na primeira juventude do protagonista, a busca de horizontes mais abertos, o abandono da casa paterna, uma série de aventuras que não sejam meramente uma sucessão de episódios, mas sim etapas de um processo de desenvolvimento, embora este não seja necessariamente linear, sendo antes marcado por erros, enganos e recuos antes de chegar a seu termo. Mas, dentro dessas semelhanças, as diferenças são fundamentais. $O$ romance de formação, surgido em finais do século XVIII, nasce das aspirações burguesas a uma educação universalizante, que ultrapassasse as limitações a que seus protagonistas estariam de antemão condenados. Isso fica claro numa passagem chave de Os anos de aprendizado de Wilhelm Meister. Numa carta ao amigo Werner, seu futuro cunhado e antípoda no que se refere às aspirações na vida, Wilhelm afirma seu desejo de buscar essa formação universalizante, que ele considera apanágio da nobreza, em contraposição à educação utilitária que lhe estaria destinada como burguês cuja perspectiva mais imediata seria suceder o pai à frente dos negócios familiares. E é em busca de satisfazer essa sua aspiração que Wilhelm deixará a casa paterna para juntar-se a uma companhia teatral, primeira etapa e primeiro grande engano de sua trajetória. Mais tarde ele descobrirá que seu desenvolvimento vem sendo desde algum tempo monitorado pela Sociedade da Torre, uma associação de homens nobres e de aspirações elevadas que, fiéis à doutrina do 
aprendizado pelo erro, nos momentos decisivos intervém para ajudá-lo a encontrar seu caminho. Por fim, seu casamento com a nobre Natalie lhe abre as portas do mundo da nobreza a que aspirava desde o início. Desse modo, num modelo tradicional, o protagonista de um romance de formação busca algo que se poderia classificar como um ideal. É verdade que, em sua busca, Wilhelm não deixa de recorrer à fraude, quando desvia o dinheiro que seu pai lhe confiara para as operações comerciais de que o encarregara para investir em sua carreira teatral. Nessa passagem do romance, como nota Wilma Patrícia Maas, Wilhelm age como um pícaro, o que colocaria em xeque a afirmação de Koopmann de que a ideia de formação e a prática da impostura são mutuamente exclusivas ${ }^{8}$. Mas Wilhelm justifica seu ato aos olhos do leitor com o elevado propósito por trás de sua fraude, e o desenrolar do romance parece confirmá-lo.

O pícaro genuíno é diferente. É desde o início alguém que se encontra à margem, o que vale dizer que seu lugar natural entre as personagens literárias seria antes a galeria dos anti-heróis. Isso significa que seu ponto de partida é consideravelmente inferior ao do protagonista de um romance de formação, e seu ponto de chegada, mesmo quando sua trajetória é apresentada como um sucesso, um ponto de equilíbrio entre eu e mundo, também fica muito aquém das aspirações deste, como podemos ver no Lazarillo de Tormes, obra em geral considerada como a fundadora do gênero. Lázaro descendo de uma família bastante irregular, e ao fim de suas aventuras só consegue se estabilizar na profissão de pregoeiro, que o coloca numa das posições mais baixas da escala social ${ }^{9}$. Além disso, seu casamento, ao contrário do de Wilhelm Meister, não passa de uma fachada para esconder as relações ilícitas de sua esposa com o arcipreste de San Salvador, que se faz de seu protetor. Para o pícaro, portanto, as fraudes e burlas são um meio de sobrevivência indispensável, e a ascensão que propiciam é das mais modestas. Estão muito distantes de seu universo a aspiração burguesa de uma formação universal, com uma janela aberta para o mundo das artes, e a idealização das experiências eróticas como elevação intelectual, comuns nos romances de formação tradicionais ${ }^{10}$.

Colocando as Confissões do impostor Felix Krull sob essa perspectiva, podemos dizer, então, que desde sua origem a personagem traz consigo, combinadas, as marcas dos protagonistas de ambos os gêneros, dependendo do ângulo pelo qual os encararmos. Sua família "burguesa" é também "licenciosa", e não goza de respeitabilidade irrestrita junto à sociedade local, embora more numa villa luxuosa e suas recepções sejam sempre cheias e animadas. Todas as suas ambiguidades futuras serão

\footnotetext{
${ }^{8}$ MAAS, Wilma Patrícia, op. cit., p. 73.

9 GONZÁLES, Mario M. "Lazarillo de Tormes: Estudo crítico". In: Lazarilho de Tormes. Tradução de Heloísa Costa Milton e Antonio R. Esteves. São Paulo: Editora 34, 205, p. 215.

${ }^{10}$ MAAS, Wilma Patrícia, op. cit., p. 62.
}

121 | D O S S I Ê : ROMANCE DE FORMAÇ̃̃O - CAMINHOS E DESCAMINHOS DO HERÓI 
decorrentes dessa primeira, tudo que ele fará terá duas faces. Se podemos chamar tranquilamente de fraudes algumas de suas atitudes, como falsificar a letra do pai para escrever cartas justificando sua ausência na escola ou encenar com perfeição uma doença para o mesmo fim, não podemos deixar de reconhecer nelas a manifestação de um talento de artista. O mesmo que, quando ele posa travestido de divindade, de personagem histórica ou mesmo nu para seu padrinho, o pintor Schimmelpreester, se manifesta com aparente inocência. Apenas aparente, pois antecipa seu empreendimento mais ousado: a troca de identidade com o marquês de Venosta.

Mais tarde, depois da falência da fábrica de espumante e do suicídio do pai, quando ele e sua mãe tentam se estabelecer em Frankfurt, Felix também desempenhará papéis dúbios. Vagando pelas ruas da grande cidade como um miserável que posa de flanêur, viverá diversas aventuras, entre elas o relacionamento com uma prostituta húngara, Rosza. Ao mesmo tempo que demonstra simpatia e afeto por todas as mulheres desta condição, ele não deixa de aceitar o dinheiro dela, comportando-se como um gigolô, mas um gigolô que condena a violência que os outros de sua espécie praticam contra suas amantes. E não perde de vista o propósito de dar um caráter nobre à sua narrativa, referindo-se à relação entre ele e Rosza como uma "severa escola de amor".

Não são apenas manifestações de uma desfaçatez sem limites. Por trás de todas essas ambiguidades está um princípio filosófico, que Felix interpreta à sua própria maneira, assim como faz um uso muito peculiar do conceito goethiano de mérito inato. Segundo as palavras do próprio autor, nas origens do romance estão as considerações de Arthur Schopenhauer, em $O$ mundo como vontade e representação, sobre o véu de Maya, que cobre os olhos dos mortais, fazendo-os ver um mundo que se assemelha ao sonho ${ }^{11}$. Comentando essa passagem num ensaio famoso, Thomas Mann tira daí a conclusão de que a variedade no tempo e no espaço é apenas aparência, e a diversidade e a diferença se tornam, sob esse ponto de vista, mera ilusão ${ }^{12}$. Na trama do romance, essa ideia encontra sua expressão mais acabada naquilo que poderíamos chamar a "teoria da permutabilidade" de Felix. Observando de seu posto de ascensorista e garçom a movimentação da sociedade que se hospeda num hotel de luxo em Paris, Felix chega à conclusão de que várias daquelas pessoas poderiam permutar entre si suas posições sem que ninguém destoasse de seu papel. Assim, podemos dizer que sua descrição de si mesmo nas primeiras páginas do romance o apresenta como alguém que desde cedo se exercitou

${ }^{11}$ SCHOPENHAUER, Arthur. O mundo como vontade e representação. Tradução de M. F. Sá Correia. Rio de Janeiro: Contraponto, 2001, p. 14.

${ }^{12}$ MANN, Thomas. “Schopenhauer”. In: Leiden und Größe der Meister. Frankfurt: Fischer, 1957, p. 188.

122 | D O S S I Ê : ROMANCE DE FORMAÇ̃̃O - CAMINHOS E DESCAMINHOS DO HERÓI 
para praticar essa permutabilidade, e só então nos damos conta da extensão de seu aprendizado quando encenava estar doente para faltar à escola ou se travestia para servir de modelo ao pintor seu padrinho. Da mesma maneira, sua família tem tantos traços burgueses genuínos (a formação francesa do pai, a casa luxuosa sempre cheia de comensais) quanto os característicos da família de um pícaro (o pendor para a falcatrua do pai, a sensualidade exacerbada e algo grosseira da mãe e da irmã). E o protagonista, em especial, se esmera cada vez mais para desenvolver ambas as tendências em igual medida. Seus pendores para a encenação têm tanto a dimensão da arte quanto da impostura, e nos damos conta pela primeira vez de sua eficácia e do grau de perfeição a que chegou no capítulo em Felix narra como conseguiu ser dispensado do serviço militar simulando sofrer um ataque devido a uma enfermidade que o tornaria inapto para ele, mas dando, mesmo ao leitor que está ciente da fraude, a impressão de que de fato sofre esse ataque, pois o efeito que alcança não parece de modo algum ser apenas fingido.

Similar é sua maneira de interpretar as passagens marcantes de sua vida. Logo ficará claro que a "severa escola de amor" que ele frequentara com Rosza será de grande valia para sua vida futura, embora o romance, em seu estado inacabado, só nos deixe conhecer uma dessas ocasiões: a noite passada nos braços de Diane Philibert. Ele roubara as joias dela quando ambos passavam pela inspeção da alfândega na fronteira francesa (o que, fiel ao seu método, em sua descrição ele transforma num ato imperceptível, guiado pelo acaso). Ao reencontrá-la no hotel, tem a oportunidade de viver uma aventura erótica com ela. Mas jamais poderia imaginar as surpresas que lhe estavam reservadas. Pois logo ela se revela como alguém que também vive em duas esferas distintas. De um lado, ela é Madame Houpflé, a burguesa casada com um rico fabricante de vasos sanitários; de outro, Diane Philibert, uma mulher lasciva, com pendor para a perversão. Ajudando a evitar a vulgaridade dessa combinação tão batida, uma intensa imaginação poética: Diane é escritora de verdade, provavelmente uma típica representante do esteticismo fin-de siècle. A reunião desses elementos todos desnorteiam Felix, que sucessivamente se encanta com uma conquista tão fascinante, e logo depois se ofende quando ela o trata como um simples criado com o qual se entrega ao prazer infinito da degradação, num jogo erótico que ele não consegue compreender. Mas o leitor não pode deixar de notar que essa personagem tão exuberante confirma Felix em sua duplicidade. Pois se de início se excita ao saber que se trata de um ladrãozinho que lhe surrupiara as joias na alfândega, logo a seguir o envolve numa aura de poesia e o eleva às alturas de Hermes, o deus ladrão. Do mesmo modo, o produto do furto que ela o incentiva a fazer no escuro, enquanto se deleita em ouvi-lo remexer suas coisas, terá duas dimensões inseparáveis: será um "butim de roubo e arroubo", um 
fruto tanto do furto quanto do amor. Não lhe será dado em pagamento pelo prazer que ele lhe proporcionara e do qual também compartilha, "dando-lhe o seu melhor e desfrutando dela", ao contrário, será algo de que ele se apropriará por que tem o direito de fazê-lo.

Que Felix não é apenas um impostor vulgar buscando sobreviver de suas fraudes, prova-o sua atitude diante de outras personagens com as quais vai se relacionando ao longo da narrativa: Stanko, o colega de hotel, cuja proposta para assaltarem juntos uma casa ele recusa, e, sobretudo, aquelas que lhe oferecem uma oportunidade de impostura aparentemente vantajosa: a jovem Eleanor Twentyman, que lhe propõe que fujam juntos e ele a engravide a fim de forçar o aceite da união desigual por parte dos pais dela, e Lord Kilmarnock, que lhe oferece fazer dele seu herdeiro caso aceite se tornar seu companheiro de vida sob o disfarce de um mordomo, ou mesmo de um filho adotivo. Em ambos os casos a impostura é por demais evidente, totalmente desprovida de qualquer possibilidade de se lhe atribuir uma dimensão positiva, pelo contrário, o marcaria para sempre como um aproveitador dos sentimentos que aquelas duas personagens infelizes demonstram por ele, e talvez por isso ele não se sente minimamente atraído por nenhuma dessas ofertas, embora, mais uma vez demonstrando seu caráter complexo, tenha plena consciência do sofrimento que causa aos dois pretendentes ao recusá-los, e sinta sincera compaixão por eles.

Vamos aí o quanto, à sua maneira peculiar, Felix está envolvido na esfera artística, própria de tantas personagens de Thomas Mann. Em suas obras, essa esfera é sempre duvidosa. Já em Os Buddenbrook era sinal de decadência. Isso talvez ainda não fosse tão evidente no destino de Hanno Buddenbrook, por que este morre cedo demais. Mas se sobrevivesse seu destino decerto não seria diferente do de Tonio Kröger, com quem tem tanto em comum. E será Tonio Kroger, cujo nome o próprio Thomas Mann utilizava para assinar algumas de suas primeiras tentativas literárias, que afirmará ser o ofício de artista algo duvidoso, impróprio para um bom burguês. Segundo ele, "é preciso sentir-se em casa em algum tipo de prisão para se tornar um poeta"13. Felix dá um passo além: no seu desenvolvimento de artista da simulação, que poderia fazer dele um grande ator - e mais uma vez colocá-lo nas proximidades de Wilhelm Meister, cuja primeira tentativa de ampliação de seus horizontes se dá no teatro -, ele atravessa a fronteira que separa a arte do crime, e faz de suas fraudes uma arte. Aqui se revela por inteiro a extensão produtiva da teoria da permutabilidade de Felix. Pois ao assumir em todas essas ocasiões as duas faces - a do burguês e a do pícaro - ele de fato a coloca em prática, e

\footnotetext{
${ }^{13}$ MANN, Thomas. "Tonio Kröger". In: A Morte em Veneza e Tonio Kröger. Tradução de Herbert Caro (A Morte em Veneza) e Mário Luiz Frungillo (Tonio Kröger). São Paulo: Companhia das Letras, 2015, p. 112.
}

124 | D O S S I E E : ROMANCE DE FORMAÇ̃̃O - CAMINHOS E DESCAMINHOS DO HERÓI 
suas imposturas são bem-sucedidas justamente por que ele encarna em si os dois princípios, ele contém em si todas as dimensões que podem ser permutadas entre si, e disso faz parte também sua bissexualidade declarada, embora não efetivamente vivida.

Demonstrando total confiança nessa teoria, Felix embarca em sua maior aventura: a troca de identidade com o Marquês de Venosta. Este era um frequentador assíduo do hotel Saint James and Albany, em que Felix trabalha. Originário de Luxemburgo, o marquês se encontra em Paris supostamente para estudar e desenvolver seus dotes artísticos. Envolve-se com Zaza, uma atriz de teatro de revista e de bom grado a desposaria, não fosse a oposição decidida de seus pais, ciosos da posição que a família ocupa. Temendo que a situação se tornasse irremediável, estes imaginam um ardil para afastá-lo da amante. Propõem-lhe uma viagem de formação ao redor do mundo. $\mathrm{O}$ marquês, que não quer de modo algum se separar de Zaza, descobre em Felix o substituto ideal para empreender a viagem em seu lugar e enganar seus pais com uma correspondência enviada das diversas partes do mundo que deve visitar. As habilidades que ele desenvolvera assumindo identidades diferentes ao posar para seu padrinho e falsificando a caligrafia do pai serão aqui levadas a um novo grau de perfeição. Felix assume integralmente a identidade de Venosta e parte para Lisboa, a primeira etapa de sua viagem, de onde deveria embarcar num navio para a Argentina. Durante a viagem trava relações com o Professor Kuckuck, um paleontólogo alemão estabelecido na capital portuguesa, cuja ciência lhe desperta um interesse ainda não demonstrado anteriormente.

Durante a maior parte do tempo de sua estada em Lisboa, Felix orbitará em torno da família Kuckuck, fazendo-se passar pelo marquês de Venosta e cortejando a filha do casal, a bela e inacessível Zouzou. Em suas relações com a moça, veremos a que ponto Felix de fato encarnou o papel que assumiu: ele de certa forma projeta nela uma espécie de amor saudoso por Zaza, a amante do verdadeiro marquês, chegando a chamá-la assim por engano. Zouzou, por outro lado, parece intuir o que se passa com seu pretendente, pois desde o primeiro momento o trata com desdém e ironia. Não obstante, termina por sucumbir quando ele lhe mostra uns desenhos que fizera, supostamente inspirado por ela. São, na verdade, desenhos que o verdadeiro Venosta fizera de sua Zaza nua, aos quais Felix acrescenta traços de Zouzou. A visão deles a desarma e lhe vence a resistência. O triunfo de Felix só não se consuma por que ambos são surpreendidos pela mãe da moça que, numa reviravolta vertiginosa, o afasta dela e mais uma vez envolve Felix nas redes de uma aventura erótica inesperada. Com essa cena se encerra o que deveria ser apenas a primeira parte do romance, e ficamos privados de seu desenvolvimento posterior. 
A conquista inesperada da Sra. Kuckuck não é único grande triunfo de Felix em Lisboa. Antes disso ele fizera uma visita ao embaixador de Luxemburgo, que se oferecera para apresentá-lo ao rei de Portugal. A visita é tão bem-sucedida que lhe valerá uma condecoração e um título de nobreza genuíno, a Ordem do Leão Vermelho. Assim, Felix alcança sem maiores esforços aquilo que Wilhelm Meister busca ao longo de todos os seus anos de aprendizado, e só pode alcançar filiando-se à Sociedade da Torre e casando-se com a nobre Natalie. Mas aqui se revela ao leitor que o que se passa no romance de Thomas Mann é uma inversão daquilo que temos no de Goethe: durante a conversa em que Venosta lhe faz a proposta de assumir seu lugar, Felix afirma não conhecer muita mitologia, ao que o marquês lhe responde:

E para que precisa disso? Erudição, sobretudo erudição profunda, não é para o gentleman. Isso ele tem em comum com o nobre. É uma boa tradição do tempo em que um membro da aristocracia só precisava saber montar um cavalo com dignidade, e não aprendia mais nada além disso, nem mesmo a ler e escrever. ${ }^{14}$

Ou seja: aquilo que Wilhelm Meister acredita ser apanágio da nobreza, uma formação universal, deixou de ser uma aspiração desta, tornando-se uma necessidade burguesa.

Aqui podemos ver o quão longe Thomas Mann leva a interpretação das considerações de Schopenhauer expressa pelo romance, e o significado mais profundo de da teoria da permutabilidade. Para onde quer que olhe, Felix só vê pessoas agindo como atores desempenhando um papel. As pessoas com que se relaciona no hotel Saint James and Albany escondem, por baixo do brilho de uma vida de luxo e riqueza, abismos insondáveis e insatisfações de toda ordem. Madame Houpflé vive num acordo conjugal tácito com o marido: ele a trai com atrizes do teatro de revista, ela com os mocinhos, adolescentes com os quais satisfaz suas fantasias eróticas, e seu talento de escritora de romances "muito belos e inteligentes" faz submergir sob uma aura poética a sordidez da situação. A proposta da jovem Eleanor Twentyman de que ele, um simples empregado de hotel, a engravide para criar uma situação irreversível, resultaria numa história das mais vulgares, mas é produto de seu desejo torturante de viver uma aventura amorosa intensa, que rompa a estreiteza de seu horizonte familiar e social. A homossexualidade de Lord Kilmarnock o obriga a uma vida dissimulada, e seu desejo de constância e estabilidade amorosa não vê outra saída senão o sonho de perpetuar essa dissimulação numa relação com Felix que garantisse a aparência de respeitabilidade. Já Venosta parece querer evitar para o seu relacionamento com Zaza a solução mais corriqueira para

${ }^{14}$ MANN, Thomas. Confissões do impostor Felix Krull, op. cit., p. 211.

126 | D O S S I Ê : ROMANCE DE FORMAÇ̃̃O - CAMINHOS E DESCAMINHOS DO HERÓI 
alguém de sua classe, que seria embarcar num casamento de conveniência e manter com ela uma relação extraconjugal. Também a família Kuckuck, apesar da reputação científica do pai, da altivez da mãe e das veleidades de independência da filha, termina por revelar o seu outro lado. A Senhora trai o marido com Felix - já não o terá feito outras vezes? E a insolente Zouzou, por desejo expresso do pai, em breve se casará com o assistente dele, um arranjo dos mais convencionais.

O quadro composto por essas personagens não deixa dúvidas: o mundo descrito por Felix em sua autobiografia se assenta sobre bases muito instáveis. Se ao seu redor Felix só encontra uma sociedade feita de aparências, se o próprio brilho eterno da cidade de Paris não esconde suas misérias, como podemos ver pelo bando de excluídos que o assediam quando se senta num café, então sua teoria da permutabilidade encontra sua mais plena justificação.

As Confissões do impostor Felix Krull compartilham com muitos romances publicados entre o final do século e o período entre-guerras a visão de uma sociedade desprovida de substância, fundada nas aparências ou agarrando-se a símbolos de estabilidade que disfarcem o solo movediço sobre o qual procura se equilibrar. Em Effi Briest (1894-5), a obra-prima de Theodor Fontane, autor que deu o melhor de si já nos anos da velhice, o Barão von Instetten desafia e mata num duelo o sedutor de sua jovem esposa. É sem vontade que o faz, por puro apego às convenções e às aparências, e se não tivesse confidenciado a traição da esposa a um amigo, não podendo suportar a ideia de que alguém nesse mundo além das três pessoas diretamente envolvidas com a história tenha conhecimento dela, desistiria de bom grado de bater-se com o rival. Ao final do romance, depois da morte de Effi, ele confessa jamais ter deixado de amá-la, e que seu desejo era ter-lhe perdoado a traição e continuado a viver com ela. No primeiro volume da trilogia Os sonâmbulos (1930-2), de Hermann Broch, o major Von Pasenow, numa atmosfera evocadora dos romances de Fontane, busca no "romantismo da farda" um refúgio para as inseguranças da vida civil. No segundo o guarda-livros Esch busca opor à ameaça de anarquia da época uma honestidade e dignidade mais formais que reais. E Huguenau, o desertor do exército na Primeira Guerra por motivos muito distantes de um pacifismo consciente, será o novo homem dessa época, completamente desprovido de escrúpulos fundados em valores sólidos. Talvez nada seja mais evocativo do esvaziamento das aspirações burguesas de uma formação universal do que o protagonista de $O$ anjo azul (1905), de Heinrich Mann. O professor a quem os alunos, num trocadilho com seu nome de família, deram a alcunha de "lixo" (Unrat) se serve da peça A donzela de Orleans, de Friedrich Schiller, para preparar "pegadinhas" nas provas e levar os alunos à reprovação. Quando sua degradação atinge o auge, ele se utiliza do verso das folhas em que estava

127 | D O S S I E : ROMANCE DE FORMAÇÃO - CAMINHOS E DESCAMINHOS DO HERÓI 
escrevendo um livro erudito sobre Homero para escrever cartas de amor à cantora de cabaré a cujos encantos sacrificara toda sua aura de respeitabilidade e sua carreira de tirano do magistério. Todas essas personagens estão à beira do abismo, buscando escapar dele agarrando-se às ruínas de uma concepção de mundo em profunda crise. E se fôssemos citar todos os exemplos, a lista se tornaria interminável.

Se é lícito tomarmos este como o diagnóstico a respeito de sua época realizado também por esta obra de Thomas Mann, então poderemos compreender como foi possível combinar numa só personagem as figuras do protagonista de um romance de formação e a de um pícaro, e o sentido de fazê-lo: tanto as aspirações burguesas de uma formação universal quanto o julgamento moral a respeito da sociedade presentes naquelas vertentes do romance europeu dependem de bases sólidas e valores bem definidos. Num cenário de esvaziamento e redução a mera aparência dos ideais burgueses que deram origem ao romance de formação, todas as aspirações das personagens que povoam as páginas dos vários representantes dessa vertente deixam de fazer sentido. Onde as aparências dominam e são a chave para o sucesso, o charlatão está mais em casa que um burguês cheio de aspirações nobres, as burlas e falcatruas de um pícaro também perdem seu aspecto condenável, e até ganham uma aura romântica que pode conferir uma aparência de ideal àquilo que em outras circunstâncias pareceria condenável. Num contexto desses, um romance de formação pode ser também uma novela picaresca, e vice-versa.

Dá mostras do progressivo esvaziamento dos valores e significados implicados na construção de um romance como o Wilhelm Meister, o tema das mésalliances, que marca o ponto de chegada das errâncias do protagonista. Não se trata, como poderia parecer a um exame mais ligeiro, de uma solução forçada. Esse desfecho é cuidadosamente preparado pelas discussões a respeito do papel da nobreza e da hereditariedade de seus privilégios que ocupam boa parte do livro. Nem se pode também afirmar que com isso Goethe conceda toda a primazia à nobreza. Há críticas suficientes a ela, tanto nas "Confissões de uma bela alma", que constituem o Livro VI do romance quanto nos retratos dos próprios membros da aristocracia que entram em cena no decorrer da história. Se lembrarmos também a afirmação de Goethe, segundo a qual o diploma de nobreza apenas the deu aquilo que ele já possuía, podemos pensar que o desfecho se deve, do mesmo modo, ao mérito inato de Wilhelm, e que conceder a ele o acesso à nobreza não deixa de ser uma maneira de afrontá-la nos seus direitos de hereditariedade. É como se Goethe compensasse em Wilhelm as humilhações sofridas por Werther na casa do conde seu amigo, quando é expulso de uma reunião social pela chegada de outros aristocratas. Goethe mesmo sentiu isso na pele, pois sendo íntimo do Duque de Weimar 
e ocupando o cargo de Conselheiro Privado, só pôde se sentar à mesa com ele depois de lhe terem arranjado o título de nobreza.

Contudo, é evidente também que a solução guarda algo de um desfecho idealizado, distante da realidade, e o tema dificilmente terá tido novamente um tratamento semelhante. No romance balzaquiano as mésalliances têm outro sentido, o de uma conjunção de interesses muito mais concretos do que a do Wilhelm Meister. Posteriormente, em folhetins românticos como, por exemplo, O salteador (1857), de Alexandre Dumas, servem para costurar, de modo algo voluntarioso e arbitrário (para não dizer inverossímil) um happy end em que sejam corrigidas as injustiças cometidas contra o herói e a honra da heroína seja salva. Mais estranho ainda é o seu tratamento em outro folhetim, o Romance de um moço pobre (1858), de Octave Feuillet, no qual um nobre arruinado pela imprudência paterna toma sobre si a missão de salvar a honra e a situação da família pelo trabalho, recusando-se a buscar um casamento vantajoso que viesse a resolver a situação pelas vias mais curtas e costumeiras. Uma estranha atitude burguesa por parte de alguém educado como nobre. Diante da situação intrincada e quase insolúvel que criou, o autor por fim arranja ao rapaz uma inesperada herança que lhe permita se casar com a burguesa rica pela qual se apaixonara sem que seu ato mereça o conhecido epíteto pejorativo de um golpe do baú. Feuillet parece ter causado uma impressão profunda em José de Alencar, que o cita nominalmente, embora se referindo a outra de suas obras, em Senhora (1874), tentativa muito mais séria, embora quase desesperada, de purificar pelo amor um ato tão demonstrativo dos vícios da sociedade que ele quer denunciar. A uma distância ainda maior se encontra o final de Em busca do tempo perdido (191327), de Marcel Proust: Charles Swann não pode levar a amante e futura esposa, a cocotte Odette de Clèrcy, às recepções em casa dos Guermantes. Por causa dela, começa a frequentar a casa dos Verdurin, onde ela é recebida de bom grado, inclusive por que os donos desta casa gostam de fazer comentários desdenhosos sobre os salões aristocráticos, em especial o dos Guermantes. Mas durante uma longa ausência de Marcel, a Sra. Verdurin e o duque ficam viúvos e, quando regressa, já depois da Primeira Guerra Mundial, ele os encontra casados. Nada poderia falar de modo mais eloquente sobre a nova face daquela sociedade depois de 1918. Por fim, em O leopardo (1958), de Lampedusa, a decisão do príncipe Tancredi de romper o acordo tácito de desposar sua prima Concetta para se casar com a bela e sedutora Angelica, plebeia até a medula dos ossos, é a continuação na vida civil de sua decisão militar de aderir às tropas de Garibaldi durante a luta pela unificação da Itália. Uma forma de garantir a permanência na mudança, ou, nos termos do romance, que "tudo mude, para que tudo permaneça como é". 
Se o segundo volume do romance tivesse sido escrito, estava previsto que Felix se casaria e se tornaria pai. Mas não sabemos em que condições o faria. Em todo caso, naquilo que podemos conhecer da obra, ele não pensa em casamento. Quem pensa, e justamente numa mésalliance, é Venosta. Mas nem ele nem Zaza estão em busca de algo mais que viver seu amor algo insensato até o fim. O que ele quer, no final das contas, é um desfecho que a moralidade convencional sempre vedou a romances como A dama das camélias (1848) e Lucíola (1862), sob pena de se tornarem inverossímeis, e que os pais de Zouzou, controlando com decisão férrea os destinos matrimoniais da filha, não querem senão evitar.

Em todos esses casos, a mésalliance está longe de ser uma solução idealizada para os problemas propostos pelo enredo, como no Wilhelm Meister. Nunca, ou raramente, está desligada de considerações de ordem material. É antes um indício de que as aspirações expressas no romance de Goethe progressivamente deixaram de ser atuais.

As Confissões do impostor Felix Krull nos evocam um mundo pretérito, mas que é a antessala das investigações em profundidade que Thomas Mann leva a cabo em sua impressionante obra de romancista das transformações e catástrofes que marcaram a primeira metade do século XX e continuam reverberando até hoje. Põe termo a essa obra, ao mesmo tempo em que, ao fazer o enredo recuar para o final do século XIX, lhe serve de prelúdio. Sob sua aparência leve de farsa, não deixa de ser algo como um sismógrafo.

Mário Luiz Frungillo é doutor em Teoria e História Literária pela Universidade Estadual de Campinas. Foi professor da Faculdade de Letras da Universidade Federal de Goiás de 1997 a 2006. Atualmente leciona no Departamento de Teoria Literária da Universidade Estadual de Campinas (Unicamp). Traduziu, entre outras obras, O aventuroso Simplicissimus, de Hans Jacob Christoffel von Grimmelshausen (Ed. UFPR, 1998), Effi Briest, de Theodor Fontane (Estação Liberdade, 2013), Tonio Kröger, de Thomas Mann (Companhia das Letras, 2015), Conversações com Goethe nos últimos anos de sua vida, de Johann Peter Eckermann (Edunesp, 2016) e Confissões do impostor Felix Krull, de Thomas Mann (Companhia das Letras, 2018). 